\title{
Glutinous Rice (Oryza sativa L.) Cultivars Grown on Coastal Soils of Bangladesh
}

\author{
Md. Yunus Miah ${ }^{1 *}$, Mohammed Zia Uddin Kamal ${ }^{1}$, K. M. Shamsul Haque ${ }^{2}$, Kkan Golam Kuddus ${ }^{3}$ \\ ${ }^{1}$ Department of Soil Science, BSMRAU, Gazipur-1706, Bangladesh \\ ${ }^{2}$ Department of Agronomy, BSMRAU, Gazipur-1706, Bangladesh \\ ${ }^{3}$ Agrotechnology Discipline, Khulna University, Khulna, Bangladesh \\ *Corresponding author and Email: sanjidasy@yahoo.com
}

Received: 24 December 2010

Accepted: 17 March 2011

\begin{abstract}
The experiment describes the patterns of plant height, days required for booting, heading and flowering, sterility (\%), grain yield, straw yield and harvest index of three glutinous rice (Oryza sativa L.) cultivars namely, Pushbiruine, Kathalibiruine and Pakbiruine grown in the coastal saline soils of South West Bangladesh. The experiment was carried out in a Randomize Complete Block Design (RCBD) during aman season, 2003 at the experimental land of Khulna University, Khulna. The obtained results suggest that Kathalbiruine had better plant growth, considerable booting, heading and flowering periods, higher grain yield and harvest index than Pushbiruine and Pakbiruine. Thus Kathalbiruine may be considered as a potential candidate for cultivation in South-West Coastal Region of Bangladesh.
\end{abstract}

Keywords: Coastal Bangladesh, glutinous rice and urea

\section{Introduction}

Glutinous rice (Oryza sativa L.) has some special quality in terms of fineness, aroma, taste and protein contents (Kaul et al., 1982). In Bangladesh, over $30 \%$ of the net cultivable area is in the coast (Brammer, 1971) and glutinous rice can be well cultivated in South West Coastal Region (SWCR). Some of the important glutinous rice cultivars are Pakbiruine, Pushbiruine and Kathalibiruine (Paul, 2004). The demand for glutinous rice is also increasing in the country and in the European Union (Bocchi et al. 1995). Further, with social and cultural significance, glutinous rice has its historical traditions too (Golomb, 1976). However, the broader and extensive cultivation of this glutinous rice necessitates selection of suitable varieties that may perform well in the coastal regions, where the cropping intensity is rather low. Although rice (Oryza sativa L.) is the principal food of Bangladesh and commendable development in non-glutinous rice has been made, scarce research so far has been conducted on glutinous rice. This experiment was therefore, initiated to evaluate the growth and yield performance of three glutinous rice cultivars namely Pushbiruine, Kathalibiruine and Pakbiruine in the saline soil of South West Coastal Region of Bangladesh (SWCRB).

\section{Materials and Methods}

The study was conducted at the Khulna University high land field during July to December, 2003. The field is situated in the Agroecological Zone (AEZ) of Gangetic Tidal Floodplain. The soil of the field was loamy to clay loam having a of $\mathrm{pH} 7.9$ to 8.3 with low fertility status and salinity range of 0.85 to 2.24 $\mathrm{dSm}^{-1}$. The land was opened with a tractor and was ploughed and cross ploughed followed by 
laddering to bring under good puddled conditions for transplanting rice seedlings. Full doses TSP (50 kg ha $\left.{ }^{-1}\right)$ and MP (35 kg ha $\left.{ }^{-1}\right)$ were applied as basal at final land preparation. Urea $\left(88 \mathrm{~kg} \mathrm{ha}^{-1}\right)$ was applied in four splits namely, at transplanting and 10, 25 and 45 DAT (days after transplanting), respectively. The prepared block with the $0.5 \mathrm{~m}$ border pathway, consisted of 15 plots with a unit plot size of $5 \times 3 \mathrm{~m}^{2}$. Three uncontaminated and homogenous transplanted seedlings of the varieties- Pushbiruine, Kathalibiruine and Pakbiruine were transplanted in each hill with spacing of $20 \mathrm{~cm} \times 20 \mathrm{~cm}$ between rows and hills. Gap filling when needed was done within one week of transplanting.

Data on seed germination, plant height, booting, heading and flowering periods, sterility encompassing grain weight, straw yield and harvest index were collected from eight randomly selected plants coupled with the avoidance of before and after harvesting border effect. The experiment was laid out in randomized complete block design (RCBD) with five replications and statistical analyses were carried out with a statistical package MSTAT-C.

\section{Results and Discussion}

\subsection{Seed Germination}

The three rice cultivars showed a significant $(\mathrm{p} \leq 0.01)$ variation in seed germination (Figure 1). Before sowing seed germination ranged from 68 to $74 \%$, while after sowing that ranged from 80 to $82 \%$, respectively. Kathalbiruine attained the highest germination (82\%) and the lowest was recorded in Pakbiruine $(68 \%)$. The finding suggested that the seed germination performance of the three rice cultivars used for the experiment lied in the acceptable range for cultivation.

\subsection{Plant height}

No significant effect of the rice cultivars on plant height at 28, 50 and 73 DAT was observed though the plant height was significantly $(\mathrm{p} \leq 0.01)$ influenced by the cultivars at maturity (Table 1). At harvesting stage, Pakbiruine $\left(\mathrm{V}_{3}\right)$ attained the lowest plant height $(151.12 \mathrm{~cm})$ with the intermediate $(153.40 \mathrm{~cm})$ by Pushbiruine $\left(\mathrm{V}_{1}\right)$ and the highest $(162.00 \mathrm{~cm})$ by Kathalibiruine $\left(\mathrm{V}_{2}\right)$. Characteristically rice varieties differ in their heights (BRRI, 1991; Sawant et al. 1986).

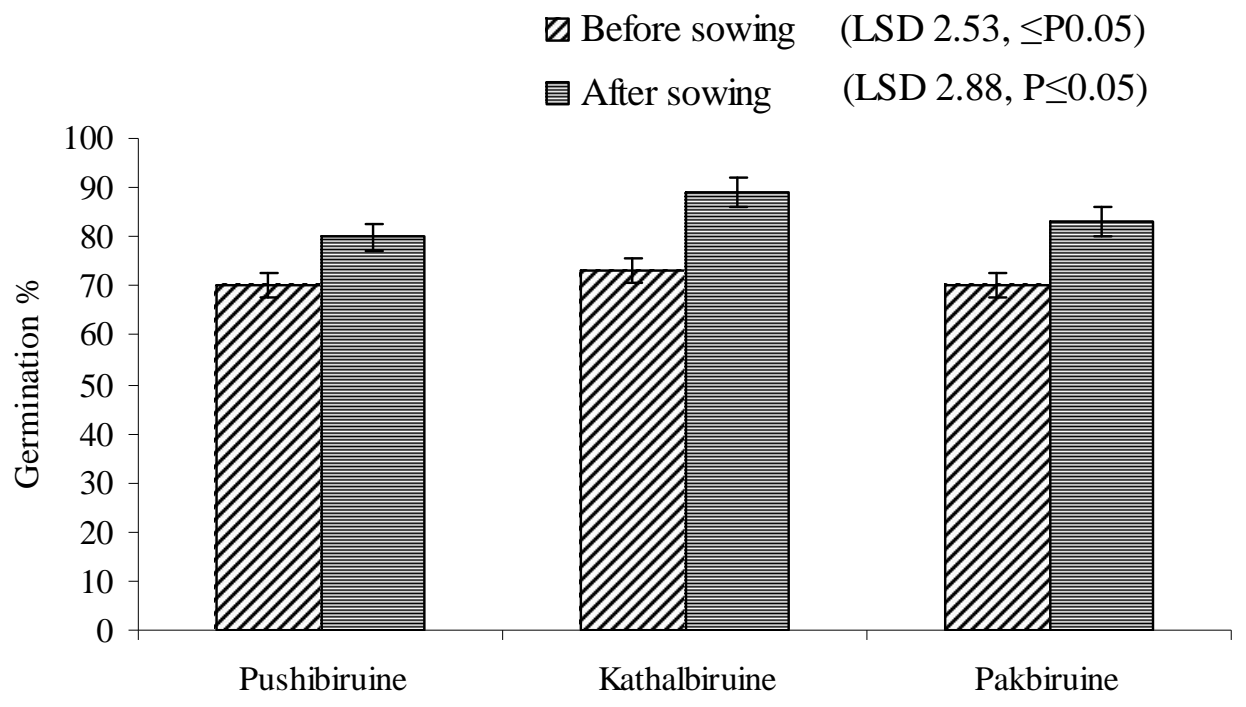

Fig. 1. Effect of varieties on seed germination 
Table 1: Differences in plant height in three glutinous rice cultivars during growing period

\begin{tabular}{l|c|c|c|c}
\hline \multirow{2}{*}{ Variety } & \multicolumn{4}{c}{ Plant height (cm) } \\
\cline { 2 - 5 } & 28 DAT & 50 DAT & 73 DAT & Harvesting time \\
\hline Pushibiruine & 47.08 & 76.64 & 117.36 & 153.40 \\
Kathalbiruine & 48.44 & 82.88 & 123.60 & 162.00 \\
Pakbiruine & 46.80 & 75.56 & 109.52 & 151.12 \\
CV\% & 8.60 & 6.61 & 7.50 & 1.69 \\
LSD & -- & -- & -- & 7.18 \\
Level of significance & NS & NS & NS & $* *$ \\
\hline
\end{tabular}

N. B.: CV = Coefficient of Variation, LSD $=$ Least Significant Difference, NS = Non significant, $* *$ $=$ Significant at $1 \%$ level, DAT $=$ Days After Transplanting

\subsection{Booting, heading and flowering}

As shown in Table 2, the three cultivars did not show any variation in days required to booting, heading and flowering. However, Kathalibiruine $\left(\mathrm{V}_{2}\right)$ required the maximum number of days for booting, while minimum days was required for Pakbiruine $\left(\mathrm{V}_{3}\right)$. In general, glutinous rice varieties grown in the SWCR showed no remarkable differences in days required for booting (Paul, 2004) and thus, the booting period requirement for the three cultivars were similar to those reported by Paul (2004). The highest number of days (87 and 90) required for heading and flowering was found in Kathalibiruine $\left(\mathrm{V}_{2}\right)$ and those of the lowest (85 and 89) in Pakbiruine $\left(\mathrm{V}_{3}\right)$. Variety may have differential effect on plant characters of rice as reported by Shamsuddin et al. (1988) and BRRI (1990). It has been reported that variable heading and flowering periods in rice is a common feature (BRRI, 1988). In the current investigation, different varieties needed different number of days for their heading and flowering. So, variability in the number of days required for heading and flowering in our findings are supported by those of Shamsuddin et al. (1988) and BRRI (1988 and 1990). Insignificant difference with regards of booting, heading and flowering periods among three cultivars studied reflects the varietal uniqueness on the expression of rice plant characters. Thus the varieties characterized by differential booting, heading and flowering periods demonstrated their persistent adaptation in locale of SWCRB. Further, longer booting, heading and flowering periods in Kathalibiruine $\left(\mathrm{V}_{2}\right)$ revealed that Kathalibiruine could be cultivated in flash flood or heavy rainfall hit parts of SWCRB where water stagnation caused delayed transplanting of aman rice prevails.

\subsection{Sterility, grain yield, straw yield and harvest index}

\subsubsection{Sterility}

Spikelet sterility varied significantly $(\mathrm{p} \leq 0.5)$ among the rice cultivars (Table 3 ). The highest spikelet sterility (23\%) was observed in Pushibiruine and that of the lowest was in Kathalbiruine (18\%). For aromatic rice, spikelet sterility potential differs among rice varieties (Mannan et al., 2008). In the current study, spikelet sterility was considerable in all the cultivars used. These results indicated that glutinous rice varieties possessed significantly different sterility potential which agreed with those reported by Paul (2004). 
Table 2: Differences in days required for booting, heading and flowering of three glutinous rice cultivars

\begin{tabular}{llll}
\hline \multirow{2}{*}{ Variety } & \multicolumn{3}{c}{ Days } \\
\cline { 2 - 4 } & \multicolumn{1}{c}{ Booting } & Heading & Flowering \\
\hline Pushibiruine & 82.20 & 86.00 & 89.00 \\
Kathakbiruine & 83.00 & 87.00 & 90.00 \\
Pakbiruine & 81.00 & 85.00 & 89.00 \\
CV\% & 1.75 & 1.26 & 1.58 \\
LSD & -- & - & - \\
Level of significance & NS & NS & NS \\
\hline
\end{tabular}

N.B.: $C V=$ Coefficient of Variation, $L S D=$ Least Significant Difference, NS $=$ Non significant

Table 3: Differences in sterility, grain yield, straw yield and harvest index of three glutinous rice cultivars

\begin{tabular}{lcccc}
\hline \multicolumn{1}{c}{ Variety } & Sterility $(\%)$ & $\begin{array}{c}\text { Grain yield } \\
\left(\mathrm{t} \mathrm{ha}^{-1}\right)\end{array}$ & $\begin{array}{c}\text { Straw yield } \\
\left(\mathrm{t} \mathrm{ha}^{-1}\right)\end{array}$ & $\begin{array}{c}\text { Harvest index } \\
(\%)\end{array}$ \\
\hline Pushibiruine & 23.00 & 1.69 & 7.62 & 18.2 \\
Kathalbiruine & 18.50 & 2.01 & 7.24 & 21.7 \\
Pakbiruine & 20.00 & 1.70 & 9.19 & 15.6 \\
CV\% & 6.25 & 12.35 & 15.25 & 6.19 \\
LSD & 3.5 & 0.21 & 1.65 & 0.13 \\
Level of significance & $*$ & $* *$ & $* *$ & $* *$ \\
\hline
\end{tabular}

N. B.: CV $=$ Coefficient of Variation, LSD $=$ Least Significant Difference, $* *=$ Significant at $1 \%$ level, $* *=$ Significant at $5 \%$ level

\subsubsection{Grain yield}

The grain yield among the test cultivars showed a significant $(\mathrm{p} \leq 0.01)$ variation (Table 3$)$. Kathalbiruine produced the highest grain yield (2.01 $\left.\mathrm{t} \mathrm{ha}^{-1}\right)$ and the lowest $\left(1.691 \mathrm{t} \mathrm{ha}^{-1}\right)$ was recorded in Pushibiruine. However, the grain yield of Pakbiruine and Pushibiruine was statistically identical (Table 3). These findings suggested that spikelet sterility were the major factors for such yield variation among the varieties tested as for glutinous rice, almost similar findings were reported by Mannan et al. (2008).

\subsubsection{Straw yield}

With respect to straw yield, the test cultivars showed significant $(\mathrm{p} \leq 0.01)$ variation (Table 3$)$. The highest straw yield (9.19 $\mathrm{t} \mathrm{ha}^{-1}$ ) was found in Pakbiruine and the lowest (7.24 t ha 1) was recorded in Kathakbiruine. These sorts of variability in straw yields of rice was also reported by Singh and Sharma (1987) as these authors experimentally reported that rice varieties lead to differential production of straw yields. Additionally, for glutinous rice, antagonistic grain and straw yields are also 
reported by Mannan et al. (2008). However, generalized agreement is that both grain and straw production are highly correlated with the amount of $\mathrm{N}$ use and in the current investigation, all the varieties tested were treated with the recommended dose of urea $\left(88 \mathrm{t} \mathrm{ha}^{-1}\right)$. The test varieties therefore, need further test with various $\mathrm{N}$ levels.

\subsubsection{Harvest index}

Harvest index was significantly $(p \leq 0.01)$ different among the rice varieties. The highest harvest index (21.73) was obtained in Kathalbiruine and the lowest (15.61) was found in Pakbiruine (Table 3). For rice varieties, the relationship between harvest index and yield are directly proportional; and thus higher the harvest index and the greater is the yield (Dutta et al. (1997). The results related to the harvest index variation among the rice cultivars of the current investigation is similar to those referred by Yoshida (1981).

\section{Conclusions}

This work demonstrated that glutinous rice cultivars when experimented with recommended dose of urea in the SWCB showed differential plant height, booting, heading, flowering periods, grain and straw yields etc. which are genetic characters. Among the three cultivars, Kathalbiruine showed better performance related to those characters compared to other two cultivars. However, it is suggested to carry out further experiments on coastal saline soil of South West Coastal Bangladesh for selecting a suitable cultivar and developing appropriate management practices to adapt and cultivate glutinous rice in that region.

\section{References}

BBS (Bangladesh Bureau of Statistics). 2008. Statistical Pocket Book of Bangladesh.
Bangladesh Bureau of Statistics Division, Ministry of planning, Dhaka, Bangladesh. p. 167

Bocchi, S., Sparacino, A. C. and A. Tava. 1995. Aromatic rice varieties in Italy. Preliminary research, Sementi Elette (Italy). 41 (1): 15-18

Brammer, H. 1971. Agricultural development possibilities in Bangladesh. Soil survey project technological report No. 42 (published by United Nations Development Program, FAO (Rome).

BRRI. 1988. Annual Report for 1988. BRRI, Gazipur. pp. 88-91

BRRI. 1990. Annual Internal Review Report. Soil and fertilizer management programme. BRRI, Gazipur. IIB. pp. 2-31

BRRI. 1991. Annual Report for 1991. BRRI, Gazipur. pp. 2-23

Golomb, L. 1976. The origin, spread and persistence of glutinous rice as a staple crop in Mainland Southeast Asia. Journal of Southeast Asian Studies (Singapore). 7 (1): 1-15

Dutta, R. K., Baset Miah, M. A., Lahiri, B. A. and Salam, M. A.,1997. Assessment of grain yield and quality improvements in rice by modern breeding techniques in Bangladesh and projections of future rice improvements. Internatrional Rice Commission Newsletter, 46: 63-69.

IRRI. 1981. Principles and practices of rice production. John Willey and Sons. Inc., New York.

Kaul, A. K., Khan, M. R. I. and Munir, K. M. 1982. Rice quality, a survey of Bangladesh germplasm. Bangladesh Rice Research Institute, Joydevpur, Dhaka, Bangladesh. $1-178$ 
Mannan, M. A., Bhuiya, M. S. U. and Hossain, S. M. A., 2008. Effect of nitrogen on the growth and yield of traditional fine aromatic rice varieties in aman season. Annals of Bangladesh Agriculture, 12 (2): 9-17.

Paul, P. S. 2004. Performance of aromatic and glutinous rice in coastal saline soil. MS thesis, Life Sciences School, Khulna University, Khulna

Sawant, A.C., Throat, T. S. and Bosle, R. J. 1986. Response of early varieties to nitrogen levels and spacing in coastal
Asharasta. Journal of Maharastra Agricultural University, 11 (2), 182-184

Shamsuddin, A. M., Islam, M. A. and Hossain, A. 1988. Comparative study on the yield and aromatic characters of nine cultivars of Aus rice. Bangladesh J. Agril. Sci. 15 (1): 121-124

Sing, K. N. and Sharma, D. K. 1987. Response to nitrogen on rice in sodic soil. IRRN 12 (3): 45 .

Yoshida, S. 1981. Fundamentals of Rice Crop Science. Int. Rice Research Institute, Manila, Philippines. 